\title{
Introduction: development and challenges of Chinese financial markets
}

\author{
Kam C. Chan, Hung-gay Fung and Qingfeng \\ 'Wilson' Liu
}

\section{INTRODUCTION}

China's capital market grew substantially in the decade after the Shanghai Stock Exchange market opened in 1990. Despite China's impressive economic performance, the development of its capital market has encountered various hurdles. As China has evolved from a planned economy to a market-oriented economy in which the stock and bond markets have enabled Chinese corporations to raise external funds, the Chinese economy today is still dominated by banks. China is a bank-based economy overall.

Panel A of Table I.1 shows the importance of banks in China and other countries as compared to the stock market capitalization. Bank credits in China account for 141 percent of its GDP, a very high figure in comparison to other countries in East Asia and the US, implying the importance of bank loans to the Chinese economy. The numbers point to the fact that China is a bank-based economy. At the same time, China's stock market capitalization is about 39 percent of its GDP, a low figure compared to Japan ( 79 percent), Euro area (55 percent) and the US (129 percent). These figures suggest that China's capital structure (that is, the relations between the equity market and the bank loans market) remains unbalanced and underdeveloped due to limited equity financing for corporations when compared to developed countries including the traditional bankingdominated European economies (55 percent), or even with Korea (57 percent of GDP) and other emerging markets (61 percent of GDP).

It is apparent that Chinese investors primarily put their money into banks instead of investing it directly in the stock market. Savings in banks in China exceeded US\$1 trillion as of late 2005. The reliance in banks by investors and market participants to scrutinize investments in firm projects is the result of excessive noises/confounding signals in the market if they 
Table I.1 Financial structure comparison

\begin{tabular}{lcc}
\hline Panel A & Bank Credit versus Stock Market, 2004 & \\
\hline Country & $\begin{array}{c}\text { Bank credit } \\
(\%) \text { of GDP }\end{array}$ & $\begin{array}{c}\text { Stock Market capitalization } \\
(\%) \text { of GDP }\end{array}$ \\
\hline China & 141 & 39 \\
Euro area & 104 & 55 \\
Japan & 94 & 79 \\
South Korea & 80 & 57 \\
Emerging markets & 65 & 61 \\
US & 46 & 129 \\
India & 37 & 56 \\
\hline
\end{tabular}

Source: $\quad$ Wall Street Journal, 13 October 2005.

Panel B Local Currency Bond Markets, 1997 versus 2003

\begin{tabular}{lrrrrr}
\hline & \multicolumn{2}{c}{1997} & & \multicolumn{2}{c}{2003} \\
\cline { 2 - 3 } \cline { 5 - 6 } & US\$ billion & \% GDP & & US\$ billion & \% GDP \\
\hline China & 116.4 & 12.9 & & 440.4 & 31.3 \\
Korea & 45.1 & 29.1 & & 445.7 & 73.6 \\
Singapore & 23.8 & 24.9 & 67.2 & 73.6 \\
Thailand & 9.6 & 6.1 & & 58.4 & 40.7 \\
Japan & 355.5 & 19.1 & 1202.8 & 44.3 \\
US & 11997.5 & 144.5 & 17644.8 & 160.3 \\
EU15 & 7095.7 & 85.8 & 10357.3 & 98.6 \\
\hline
\end{tabular}

Source: Asia Bond Monitor, November 2004, Asian Development Bank.

would invest directly in firm projects. Thus, market reforms need to stress and improve the transparency, credibility and liquidity of the capital markets.

In terms of bond market development, Panel B of Table I. 1 shows the size of China's bond market is about 31.3 percent of its GDP in 2003. This figure again is low when compared to Singapore (73.6 percent), Japan (44.3 percent) and the US (160.3 percent). The result indicates that China's bond market is relatively underdeveloped in comparison to other countries. The bond market is another dimension that market participants can monitor and discipline in firm behavior. For the Chinese economy to achieve sustained and healthy growth, the development of its bond market is important. 
All in all, this chapter provides an overview of the development and challenges in China's capital market, while the detailed structure and components will be presented in later chapters. In a review paper of the finance literature, Chan et al. (2006) discuss the various underlying factors leading to the development of China's capital market, including the imperfect market and segmentation, regulation and stages of financial development. We will provide an updated examination of China's capital market that includes equity market, bond market, foreign exchange market and futures market. This chapter serves as a building block for readers to better understand the overall development of China's capital market.

\section{STOCK MARKET}

\section{Institutional Structure}

The Shanghai Stock Exchange and Shenzhen Stock Exchange are the two major stock exchanges in China. As of the end of 2005, there were about 1400 listed companies on the two exchanges. Since the stock market was established in the early 1990s, there have been various types of shares issued to the public: A shares, $\mathrm{B}$ shares, $\mathrm{H}$ shares and $\mathrm{N}$ shares. The A-share market trades the shares of Chinese companies limited primarily to domestic Chinese investors. The B-share market is for shares of Chinese companies traded on the exchange and they are issued to foreign investors or for Chinese investors who have foreign currencies (US or Hong Kong dollars). Some Chinese companies issue both A shares and B shares provided that they satisfy the listing requirements, such as compliance with the International Accounting Standards, a more stringent standard than the domestic counterpart. H shares are shares of Chinese companies traded on the Hong Kong Stock Exchange and thus these companies need to satisfy the listing requirements of the Hong Kong Stock Exchange. N shares are shares traded in the US stock exchanges, including the NYSE and the Nasdaq. These shares are basically American depositary receipts for the stocks of Chinese companies. Chinese companies issue B shares, $\mathrm{H}$ shares, and $\mathrm{N}$ shares to foreign investors in order to raise foreign capital.

In recent years, a mutual fund market has emerged and developed in China, which expands the landscape of China's capital market and offers more investment options to investors with both open-ended and closedended funds (Xu 2005). On 23 February 2005, China started the first exchange-traded fund, ETF, on the Shanghai Stock Exchange (Ling and Yau 2005). An ETF is similar to a mutual fund but it can be traded like a stock listed on the exchange. China 50 ETF, issued by China Asset 
Management Co., sponsored by State Street Global, tracks the 50 largest Chinese stocks on the Shanghai Stock Exchange. Foreign investors can buy China 50 ETF through the QFII (Qualified Financial Institutional Investor) program. In addition, there are several Chinese exchange traded funds available in the US and elsewhere.

The A-share market is apparently the most important component of the Chinese stock market system. This Introduction primarily focuses on this segment of the market. The growth and changes of the A-share market shape the growth of China's stock market.

\section{Policy Changes and Implications}

The Chinese government initially created the A- and B-share markets in order to maintain control because the B-share market is for foreign investors while the A-share market is for domestic investors. Thus, the segmentation of the A-share and B-share market is artificial, resulting in a considerable premium for the A-share market relative to the B-share for the same companies (Fung, Lee and Leung 2000). As the Chinese government relaxed the restrictions for domestic investors to invest in the B-share market in 2001, the barriers between the two markets gradually broke down, moving toward one market regime, although there are still differences in investor clientele between the two markets.

One thorny issue in the Chinese stock market development is the distinction between non-tradable shares and tradable shares within the A-share market. Non-tradable shares are shares held by financial institutions (called legal person shares) or by the state (called state shares). About two-thirds of Chinese shares are non-tradable shares. Nontradable shares can be exchanged between market participants at the book value, which is substantially below the market price (Huang and Fung 2004).

The current challenge for the Chinese government is to convert all nontradable shares into tradable shares. Over recent years, the sluggish price performance of the Chinese stock have been primarily due to: (a) the likely dilution of shares whenever the Chinese government expressed intention to convert the non-tradable shares into tradable shares; and (b) the overpricing of the A-shares relative to their intrinsic values. The overpricing of the Chinese shares is probably the result of limited investment opportunities for Chinese residents who have accumulated a large amount of savings. The Chinese government has implemented, within recent years, several measures in hopes to boost its bearish stock market, including the following by the China Securities Regulatory Commission (CSRC) in reforming the stock market. 
First, the CSRC allows controlling shareholders to buy stocks in the open market to stabilize the price, sending a signal to the market that large shareholders of the companies are, instead of cashing out, serious about the pricing of the stock. Similarly, companies are allowed to start a series of stock repurchase programs if they feel the stock prices are excessively depressed and undervalued.

Second, the CSRC has started the conversion of non-tradable shares to tradable shares, initially from certain types of companies. There has been a general policy allowing the conversion of non-tradable shares into tradable shares provided that the board of the companies and the public shareholders approve the deal. The conversion of non-tradable shares has important implications on Chinese corporate governance issue, and on the further growth of the stock market. As non-tradable shares, including state shares, represent the majority control rights, sales of these non-tradable shares signal to the market that the Chinese government no longer wants to retain control of the listed companies. This policy can potentially reduce the tension between major and minority shareholders and alleviate the conflict of interest issue. When all shares are tradable, the companies will be free to issue derivatives such as warrants and options.

Third, a rule has recently been implemented that requires approval from the majority of minority shareholders for key projects to be undertaken by firms. This policy allows the minority stockholders to have influence on corporate decisions with the goal of mitigating the conflict between majority and minority stockholders that has been prevalent in Chinese firms. The new rule can potentially change the dynamics of corporate governance, providing valuable experiences to firms around the world.

Finally, the Qualified Financial Institutional Investor (QFII) programs were launched in December 2002. Foreign institutional investors can now invest in the A-share market, which had been off limits to them before. As QFIIs have more experience and better skills for screening stocks and making investments, they will exert pressures on domestic firms for better performance. At the same time, their investments will likely boost the Chinese stock market. The Chinese government initially allows QFIIs to have a quota of $\$ 4$ billion for their Chinese investment. As of late 2005, the Chinese government has doubled the stock quota to about $\$ 10$ billion for foreign investors in order to stimulate the stock markets.

\section{The Over-the-Counter Stock Markets}

In the late 1990 s and early 2000 s, the government was prepared to set up a NASDAQ-type over-the-counter stock market under the Shenzhen Stock Exchange that would have allowed high-tech companies to be listed to raise 
equity capital with relaxed listing requirements. The proposed market, called 'the second board' by investors, was intially named the Growth Enterprise Board in May 2000. However, the preparation work was halted by the authorities in light of the ensuing market crash of the NASDAQ and other regional growth-oriented stock markets.

The preparation for the new board resumed in early 2004. On 17 May 2004, the CSRC issued the Implementation Scheme of the Establishment of the Small- and Medium-Enterprise Block (SMEB) in the Shenzhen Stock Exchange. On 27 May 2004, the SMEB was formally launched. It was deemed widely as the beginning of the second board in Chinese stock market history. The SMEB was meant to be a component of the main board but it allows high-growth and high-tech companies to be listed.

As of December 2005, 50 companies had been approved to go public and get listed on the SMEB. About 80 percent of these firms are privatelyheld and the rest state-owned. The SMEB basically followed the strict listing requirements of the main board with few information technology companies (for example, dot-com's) listed. Many listed companies are from the traditional industries such as pharmacy, utilities, appliances and machinery.

All companies listed on the SMEB have tradable shares after converting all non-tradable shares into tradable shares by December 2005. The announcements of the policy change of conversion appeared to have a positive effect on the market in general. When the SMEB index was first compiled and released on 1 December 2005, it was 43.9 percent higher than the base date of 7 June 2005. The price appreciation indicated the market optimism for the SMEB in light of all the listed stocks having resolved the stock circulation problem. The complete conversion of non-tradable shares to tradable shares in this market section ahead of the main board also suggested that the authorities were willing to allow the SMEB to experiment new reform measures, which might help it develop into a NASDAQ-type second board with relaxed listing requirements in the future.

By comparison, the second board has not materialized yet to become a similar market to NASDAQ in the US. There is actually a 'third board' in China's stock markets (Wang 2005). Its official name is 'the Proxy Shares Exchange System', which was set up on 16 July 2001 and traded ten stocks as of late 2005. These ten stocks are mostly stocks de-listed from the main board. If any stock on the third board is able to meet the listing requirements again, it will be transferred back to the main board. As such, this third board serves as an essential component of the delisting mechanism in China's stock markets (similar to the bulletin board in the US). On the other hand, this third board is truly an over-the-counter stock market, because it only exists among six securities brokerage firms - Shenyin 
Wanguo, Guotai Junan, Dapeng, Guoxin, Liaoning and Minfa. Investors can open a non-listed shares exchange account and trade these shares in any one of the 318 branches of the six brokerage firms. Although this third board is not related to financing technology firms, it does provide valuable experience in conducting over-the-counter trading on a separate stock trading system in China's stock markets.

In 2003, China also established a new equity exchange called the China Technology and Equity Exchange (CTEE) in Zhonguancun, Beijing (see Fung and Liu 2006). The market is primarily developed for high-tech firms because Zhonguancun, also known as 'China's Silicon Valley', is the location of many technology companies. In this market, some special types of securities, including private equity and non-performing loans, were traded, adding another layer of flexibility to high-tech firms to finance their projects. The CTEE merged with the Beijing Equity and Assets Exchange in 2004 to form the China Beijing Equity Exchange in Beijing. The exchange serves as a major equity transaction platform for the transfer of ownership and assets among high-tech firms (China Daily, 5 April 2004, http://www.chinadaily.com.cn). Similarly, Shanghai also opened the Shanghai Technology Stock Exchange in the late 1990s, which provides similar functions for technology firms in Shanghai.

\section{CHINA'S BOND MARKET}

China's bond market primarily consists of an inter-bank market, an overthe-counter (OTC) market, and a stock exchange market. Government bonds are listed in three markets while corporate bonds are mainly traded on the stock exchanges. The regulations and trading of the two markets differ, causing market segmentation in terms of non-uniform liquidity and pricing. Thus, there is a need to unify the two markets for future development.

The inter-bank market involves over-the-counter transactions among banks, institutional investors, enterprises and individual investors. Participating banks use the inter-bank market to adjust liquidity and asset structures, while the People's Bank of China (PBOC), the central bank, conducts open market operations for monetary policies in this market.

There are spot and repurchase transactions in the inter-bank market. Generally speaking, the repurchase transactions are more active than the spot transactions. Bond repurchase is a short term financing method involving both parties of the transaction taking bonds as pledges. The borrower (the repurchaser) agrees with the lender to return the borrowed funds as specified in the agreement to the lender (counter repurchaser) who will return the pledged bonds as collaterals to the borrower on a certain day in 
the future. Spot transaction involves the transfer of bond ownership based on an agreed-upon price.

Corporate bonds can be categorized into general corporate bonds and convertible bonds. They are listed and traded on the two stock exchanges (Shanghai and Shenzhen Stock Exchanges). The Ministry of Finance issues treasury bonds in either market or in both markets simultaneously. Joint venture companies in which foreign firms have partial ownership can engage in securities investment and fund management, and thus they can trade either Chinese government or corporate bonds.

\section{Treasury and Corporate Bonds}

Table I.2 shows the distribution of different types of bonds in China and other Asian countries. Several implications are noteworthy. First, the growth of China's bond market has been impressive. The growth rate was around 25 percent per year from 1997 to 2003, higher than those of Korea and Singapore, and only lower than that of Thailand. Second, the size of the Chinese bond market, which is about 31.3 percent of the GDP, is still the lowest percentage among all Asian countries in question. Korea's bond

Table I.2 Sizes of local currency bond markets

\begin{tabular}{lcrr}
\hline & $\begin{array}{c}\text { Annual growth rate (\%) } \\
1997-2003\end{array}$ & \multicolumn{2}{c}{ Amount in 2003 } \\
\cline { 3 - 4 } & & \$ billion & \% GDP \\
\hline China & $\mathbf{2 4 . 8}$ & $\mathbf{4 4 0 . 4}$ & $\mathbf{3 1 . 3}$ \\
Government & 27.3 & 287.4 & 20.4 \\
Corporate & 11.6 & 12.2 & 0.9 \\
Financial Institutions & 22.0 & 140.8 & 10.0 \\
Korea & $\mathbf{2 2 . 7}$ & $\mathbf{4 4 5 . 7}$ & $\mathbf{7 3 . 6}$ \\
Government & 30.3 & 124.3 & 20.5 \\
Corporate & 19.8 & 157.3 & 26.0 \\
Financial Institutions & 21.2 & 164.1 & 27.1 \\
Singapore & $\mathbf{1 8 . 9}$ & $\mathbf{6 7 . 2}$ & $\mathbf{7 3 . 6}$ \\
Government & 19.0 & 37.1 & 40.6 \\
Corporate \& Fin Inst. & 18.8 & 30.1 & 33.0 \\
Thailand & $\mathbf{3 5 . 2}$ & $\mathbf{5 8 . 4}$ & $\mathbf{4 0 . 7}$ \\
Government & 116.3 & 30.7 & 21.4 \\
Corporate & 13.5 & 19.3 & 13.5 \\
Financial Institutions & 83.0 & 8.4 & 5.8 \\
\hline
\end{tabular}

Source: Asia Bond Monitor, November 2004, Asian Development Bank (http://asianbonds online adb.org). 
market is about 73.6 percent of its GDP, while Singapore is also 73.6 percent, more than double the percentage in China. Third, the corporate bonds in China account for 0.9 percent of GDP, which is by far the lowest and points to an underdeveloped corporate bond market. In contrast, the corporate bond markets are 26.0 percent of GDP in Korea and 33.0 percent in Singapore. Currently, the interest in the convertible bond market has been growing rapidly and it has the potential to become a major component of China's bond market in the future.

Bonds from financial institutions (10 percent of GDP) and Treasury bonds (20.4 percent) were the key components of the Chinese bond market in 2003. Financial institution bonds in China are called F-bonds. There are two main kinds of financial institution bonds: policy financial institution bonds (policy F-bond) and special financial institution bonds (special F-bond) for special financial needs. Policy F-bonds are issued by three policy banks, which are State Development Bank, China Export-Import Bank and China Agricultural Development Bank. These bonds are used by the Chinese government to help carry out monetary policies. In comparison, special financial institution bonds include investment fund bonds, trust income securities, certificate of deposits and bonds issued by the Ministry of Finance. Investment fund bonds were issued by state-owned investment companies to support key construction projects but they had been stopped by 1992. The Ministry of Finance issues different types of bonds such as Special Purchase bonds, Price Index Bonds and Special Bonds for different purposes.

Treasury bonds can be grouped into four categories: (a) book-entry bonds, which are paperless with lower administration costs; (b) paper-face T-bond, traded on both the OTC market and the exchanges; (c) voucher T-bonds or saving bonds for owners; and (d) Special Purchase bonds for pension funds and insurance funds (Zhang and Liu 2001).

The challenges in reforming China's bond market are many-fold. First, China needs to develop a sound legal and regulatory framework for bond issues that define property rights for investors. This framework would include the standardization of bond issues in both stock exchanges and the OTC market. Second, there is an urgent need to improve the bond issuing process and pricing mechanism. As of late 2005, there are various offering processes such as open auction and syndicated underwriting. The Chinese government has to evaluate the merits of each option and provide related rules to avoid potential pricing problems. Third, the government needs to stimulate investor demand for bonds. Currently, QFIIs are allowed to invest in the convertible bond and Treasury bond markets, which will help increase bond demands. But better transparency is needed for bond issues and bond ratings to promote investor confidence and demand in the 
market. Finally, for economies of scale purposes, it is desirable to promote regional cooperation among Asian countries to develop regional bond markets. But apparently, the denomination currency is an issue to be resolved as there is no consensus right now as to which currency should be used as the benchmark.

\section{Panda Bonds and Foreign Investors}

On 18 February 2005, the PBOC, Ministry of Finance, National Development and Reform Commission, and CSRC jointly issued the Provisional Measures for the Administration of Renminbi-Denominated Bonds in China's domestic market. The measures require the international development institutions that want to issues renminbi bonds in China to have: (a) double A or better credit ranking; and (b) more than US\$1 billion in loans and equity investments in China.

There are restrictions on handling the bond yield, proceeds and interest. The bond issuer will set the interest rate of these bonds based on the prevailing yield of the Chinese bonds verified by the PBOC. The proceeds of the bond issue cannot be converted into foreign exchange for remittance out of China. In addition, the funds should be used for medium or longterm asset loans or equity investment for construction projects in China.

The Ministry of Finance has approved several international institutions to operate in the market, including the International Finance Corporation of the World Bank, Asian Development Bank, and the Japan Bank for International Cooperation. Underwriting and distribution of the bonds are to be handled solely by domestic Chinese firms.

The Asian Development Bank (ADB), based in Manila, has launched renminbi-denominated bonds, called Panda Bonds, in the interbank market through a syndicate of underwriters with the Bank of China serving as the lead manager. The ADB has Triple A ratings by Fitch, Moody's and $\mathrm{S} \& \mathrm{P}$ and thus can provide domestic investors the highest quality investment opportunities, and standard international services and practices. The sale of domestic-currency bonds by a foreign multilateral institution signals to the market the level of maturity of China's capital market. The nickname for the bonds, panda, is similar to the US dollar denominated 'dragon bonds' that were sold around Asia during the 1990s.

The QFII program came into effect on 1 December 2002. Since then, foreign investors are allowed to purchase China's T-bonds through the QFIIs. In addition, in May 2005, the PBOC allowed the first foreign institutional investor, the Pan-Asia Bond Index Fund (PAIF), to participate in the interbank bond market. If more foreign institutions are allowed to enter this market, the interbank market is expected to grow rapidly. 


\section{Future Bond Market Development}

China's bond forward market started trading in June, 2005. This represents a positive first step toward the development of financial derivatives markets. It would help traders to hedge risks and improve liquidity in the bond markets. The forward market will also provide a pricing discovery function for the bonds and help form a market-oriented bond pricing system.

Following a 1995 bond futures trading scandal, China closed down its bond futures market and barred the trade of financial derivatives, limiting China's exchanges to handling futures based on commodities. In light of the T-bond futures experience, the regulator has issued strict rules on margins and delivery to minimize the default risk of the forward contracts. For instance, the rules for the forward trade limit the contract terms to no more than 365 days and limit the funds for net purchases by market participants to the buyers' existing managed assets, working capital or net assets in order to prevent default.

\section{FINANCIAL INSTITUTIONS}

\section{Domestic Institutions}

Three types of financial institutions in China are important and they have played an important role in the development of the capital markets since the early 1990s. They are banks, insurance companies, and securities firms. We will discuss each one briefly in the following sections and the subsequent chapters will provide more details about these financial intermediaries.

\section{The banking industry}

Chinese banks have received much attention because of their monopolistic characteristics and colossal non-performing loans resulting from policy loans under the central-planning economic system. China's four big state banks, the Bank of China, China Construction Bank, Industrial and Commercial Bank of China, and Agricultural Bank of China, account for 57 percent of all corporate loans, which go mostly to state enterprises and have a bad debt ratio of approximately 10 percent (Business Week, 22/29 August 2005).

The Chinese banking structure includes: (a) the four big state banks discussed above; (b) three state policy banks (the State Development Bank, China Export-Import Credit Bank, and China Agricultural Development Bank); (c) shareholding banks; (d) city commercial banks; (e) rural banks; and (f) foreign banks. 
The Chinese government has created four asset management companies corresponding to the four state banks respectively to deal with the nonperforming loan problem. The Great Wall asset management company was set up for the Agricultural Bank of China, Dongfang asset management company for the Bank of China, Cinda asset management company for China Construction Bank, and the Huarong asset management company for the Industrial and Commercial Bank of China (Fung and Liu 2006).

Table I.3 reports the aggregate assets and liabilities for four major types of banking institutions in China. Panel A shows that the debt ratio (total debt to total asset) of the banking institutions on average was about 96 percent in 2003-2004, indicating the capital adequacy ratio in China is well below the global standard rate of 8 percent, as specified by the International Basel Standards for banks. Thus the Chinese banks may not be able to provide adequate capital protection for depositors. Similar patterns of inadequate equity capital persist across all four types of banks (state-owned banks, joint stock commercial banks, city commercial banks and other banking institutions, including rural credit operatives and postal savings).

Panel B of Table I.3 shows the amount of non-performing loans purchased by the four asset management corporations (AMCs) in 2004. The four AMCs have purchased over US\$150 billion of non-performing assets from the four big banks. The average cash recovery ratio for four AMCs is about 20 percent while the disposal ratio is about 54 percent.

Despite the large non-performing loans in the banking sector, it appears that the banking sector is not threatening the stability of the Chinese economy given the ability of the government to issue more bonds in case of emergency. In addition, Chinese government plans to privatize some state banks so that they can raise more new equity capital.

The important challenges for the Chinese banks are to manage the assets and loans efficiently (that is to mitigate the non-performing loans problems and maintain healthy profit margins) and at the same time compete effectively with the foreign banks after entry barriers to the Chinese market will be removed after 2006 in accordance with the WTO entrance agreements. In addition, Chinese banks have to cope with new technologies such as credit card processing, credit analysis, internet banking and the development of a mortgage backed securities market.

\section{The insurance industry}

As the insurance industry is an important component of China's capital market, it used to be protected by the Chinese government and shielded from foreign competition. However, as a WTO member, China has to open its domestic market doors for foreign insurers. It is conceivable that the 
Table I.3 Banking institutions

\begin{tabular}{lcc}
\hline $\begin{array}{l}\text { Panel A: } \\
\text { yuan) }\end{array}$ & \multicolumn{2}{c}{} \\
\hline & 2003 & 2004 \\
\hline All banking institutions & 27.6 & 31.6 \\
& $(26.6)$ & $(30.3)$ \\
Debt/asset & $96 \%$ & $95.9 \%$ \\
State-owned banks & 15.2 & 16.9 \\
& $(14.6)$ & $(16.2)$ \\
JSCBs & 3.8 & 4.7 \\
& $(3.7)$ & $(4.5)$ \\
City commercial banks & 1.5 & 1.7 \\
& $(1.4)$ & $(1.6)$ \\
Other banking institutions & 7.3 & 8.3 \\
& $(7.0)$ & $(7.9)$ \\
\hline
\end{tabular}

Note: The banking institutions include policy banks, state-owned commercial banks (four big banks), joint stock commercial banks (JSCBs), city commercial banks, and other banking institutions (rural commercial banks, urban credit cooperatives, rural credit cooperatives, postal savings, foreign banks and non-bank financial institutions).

Panel B: Non-performing loans of four Asset Management Corporations (AMC), 2004 (US\$ billion, using 1US\$ = 8.27 yuan)

\begin{tabular}{lccc}
\hline & $\begin{array}{c}\text { Non-performing } \\
\text { assets purchased }\end{array}$ & $\begin{array}{c}\text { Total } \\
\text { disposal }\end{array}$ & $\begin{array}{c}\text { Cash } \\
\text { recovered }\end{array}$ \\
\hline Huarong & 43.39 & 25.34 & 5.00 \\
Great Wall & 41.00 & 25.38 & 2.61 \\
Dongfang & 30.52 & 12.64 & 2.82 \\
Cinda & 37.35 & 18.27 & 6.14 \\
Total & 150.06 & 63.93 & 16.57 \\
Average recovery ratio & & $53.96 \%$ & $20.29 \%$ \\
\hline
\end{tabular}

Note: Disposal recovery ratio $=$ disposal/asset purchased; Cash discovery ratio $=$ cash recovered/total disposal.

Source: China Banking Regulatory Commissions, http://www.cbrc.gov.cn

insurance industry will undergo substantial changes as more foreign insurance companies enter the domestic market.

Table I.4, Panel A, shows the operating performance of China's insurance industry. Insurance premiums received have been increasing over 
Table I.4 China's insurance industry

\begin{tabular}{lrrrrr}
\hline Panel A: Operating performance (in billion yuan) & & & \\
\hline & 2000 & 2001 & 2002 & 2003 & 2004 \\
\hline Premiums & $\mathbf{1 5 9 . 6}$ & $\mathbf{2 1 0 . 9}$ & $\mathbf{3 0 5 . 3}$ & $\mathbf{3 8 8 . 0}$ & $\mathbf{4 3 1 . 8}$ \\
Property and casualty & 59.8 & 68.5 & 77.8 & 86.9 & 109.0 \\
Life and health & 99.7 & 142.4 & 227.4 & 301.1 & 322.8 \\
Compensation & $\mathbf{5 2 . 7}$ & $\mathbf{5 9 . 8}$ & $\mathbf{7 0 . 7}$ & $\mathbf{8 4 . 1}$ & $\mathbf{1 0 0 . 4}$ \\
Property and casualty & 30.6 & 33.3 & 40.5 & 47.6 & 56.8 \\
Life and health & 22.1 & 26.5 & 30.2 & 36.5 & 43.7 \\
Business expenses & 21.7 & 25.8 & 31.4 & 36.1 & 43.6 \\
Bank deposits & 123.5 & 193.1 & 302.6 & 455.0 & 496.9 \\
Investments & $\mathbf{1 3 0 . 3}$ & $\mathbf{1 7 1 . 3}$ & $\mathbf{2 5 0 . 4}$ & $\mathbf{3 8 2 . 9}$ & $\mathbf{5 7 1 . 2}$ \\
T-bonds & 95.6 & 79.6 & 110.8 & 140.7 & 265.2 \\
Investment funds & 13.4 & 20.9 & 30.8 & 46.3 & 67.3 \\
Total assets & 337.4 & 459.1 & 649.4 & 912.3 & 118.5 \\
Pre-tax profits & 85.2 & 125.3 & 203.2 & 267.8 & 287.8 \\
\hline
\end{tabular}

Note: $\quad$ Pre-tax Profits $=$ Premiums - Compensation - Business Expenses.

Panel B: Structure of Insurance Industry, December 2005

\begin{tabular}{lc}
\hline & No. of companies \\
\hline Domestic insurers & 44 \\
Foreign invested insurers & 41 \\
Foreign insurance representative offices & 188 \\
Joint venture companies & 271 \\
\hline
\end{tabular}

Source: China Insurance Regulatory Commission, http://www.circ.gov.cn/assay

time. In 2004, the total insurance premium has reached 431 billion yuan as compared to 159.6 billion yuan in 2000 , with an average annual growth rate of 42.6 percent. In particular, life and health insurance premiums rise faster than property and casualty premiums, reflecting the fast-growing concerns for individual well-being among Chinese consumers.

Most of the insurance companies have invested their premium in Treasury bonds and investment funds. With more premium received and a relatively slow rate of compensation, the Chinese insurance industry is making healthy profits. The pre-tax profits were 287.8 billion yuan in 2004 , more than triple the 85.2 billion yuan in 2000 . 
Table I.5 The number of securities and futures intermediaries

\begin{tabular}{lrrrr}
\hline & 2000 & 2001 & 2002 & 2003 \\
\hline Securities companies & 100 & 109 & 127 & 133 \\
Fund management companies & 10 & 15 & 21 & 34 \\
Futures brokerage houses & 178 & 200 & 179 & 186 \\
Investment advising firms & 143 & 137 & 167 & 111 \\
\hline
\end{tabular}

Source: China Securities Regulatory Commission, April 2004.

The total number of domestic insurance companies is small, 44 as of the end of 2005. Although the number of foreign invested insurance is only 41, there are a large number of joint venture insurance companies (271). Although China will still not allow foreign insurance companies to set up wholly-owned branches, their presence will inevitably grow as China gradually relaxes its restrictive policies.

\section{The securities industry}

The number of securities firms is relatively small in China. Table I.5 shows that the number of securities companies stands at 133 in 2003 as compared to 100 in 2000. This result reflects China's tight control on its securities industry, and the industry's monopolistic status. Investment advising firms dropped to 111 in 2003 from 143 in 2000. This downward trend coincides with the disappointing performance of China's stock market in recent years after the Asian financial crisis. And fund management companies grew from 10 to 34, reflecting growing interest among investors in professionallymanaged funds in a bearish market.

Regarding the reforms of the securities industry, the Chinese government has implemented two new measures to revitalize the industry, which has been plagued by liquidity problems and bankruptcy threats. First, the government has injected capital into the ailing securities firms with liquidity problems. Many local securities brokerage firms have suffered heavy losses because they offered guarantees for high returns to investors, which proved to be impossible to honor when the stock market fell consistently for eight years in the wake of the Asian financial crisis. If the securities firms' liquidity becomes a concern among investors, there will be credibility problems in the financial markets which will further depress stock market performance. Injecting a huge amount of capital into the brokerage firms will prop up the confidence of Chinese investors and help boost the stock markets. As the first stage of a broad package of government support for the securities industry, the PBOC provided loans to Shenyin \& Wanguo Securities and Huaan Securities in mid-2005 (Financial Times, 14 June 2005). 
Second, under the new rules, at the end of December 2005, foreign ownership limit in fund management firms was raised from 33 percent to 49 percent. Chinese regulators have started approving fund management ventures between commercial banks, such as the Industrial and Commercial Bank of China's joint venture with Credit Suisse Frist Boston. The new rules were aimed to increase competition and make existing fund management firms, local or joint ventures, more streamlined and effective in meeting investor needs.

\section{Globalization}

China's financial industry has been subject to global forces in various aspects. In accordance with the WTO requirements, China has to open up to global competition by allowing foreign banks, brokerage firms and insurance companies to operate in China. Second, China has also implemented rules such as the QFII program to speed up financial reforms. Third, privatization of the banks and joint ventures of the brokerage firms lead to changes in Chinese financial industries.

In addition, the China Insurance Regulatory Commission (CIRC) allowed local insurance companies to invest their foreign currency in common stocks listed on overseas exchanges that are deemed to be mature. Initially, insurance companies will be allowed to invest only in Chinese company stocks listed abroad, but the restriction could be relaxed, depending on the insurers' management capability and international stock market environment. Chinese insurers hold an estimated $\$ 10$ billion in foreign currencies. There are restrictions for these equity investments - insurers are required to use less than 10 percent of the total foreign exchange investment quota allotted by regulators to invest in overseas Chinese company stocks, with the rest invested in various types of bonds (Wall Street Journal, 20 June 2005).

\section{THE FOREIGN EXCHANGE MARKET}

China adopted a managed exchange rate regime in 1994, allowing the exchange rates to fluctuate within a tight range. The yuan's exchange rate has been pegged to the US dollar with \$US1 to 8.28 yuan. In July 2005, China allowed its currency to appreciate 2.1 percent in value in light of the pressures from the US and other Western countries. Since then, China has linked its currency to a basket of currencies that are closely tied to its international trade.

Although under the QFII program, investors can repatriate their profits and capital back to their home countries, China still maintains tight control 
on its capital account. When foreign investors trade with China, they get their renminbi earnings in other tradable currencies.

A new development of the Chinese currency has taken place between China and Hong Kong recently. Banks in Hong Kong allow deposits of Chinese currencies and credit cards in Chinese currencies. At the same time, Chinese currencies can be freely converted into Hong Kong dollars. This development basically allows partial float of the Chinese currency because Hong Kong dollars are freely converted into other currencies. In addition, some Southeast Asian countries such as Singapore, Thailand and Laos, have widely accepted Chinese currencies for business transactions.

Offshore trading on Chinese currencies has been growing in recent years. In light of the unconvertible Chinese currencies, derivatives such as nondeliverable forward contracts and currency options have been developed (Fung et al. 2004). The continual liberalization of the foreign exchange market in China and off-shore market trading will inevitably speed up the reforms in China's foreign exchange system.

\section{FUTURES MARKETS}

The first commodity futures market in China was the Zhengzhou Grain Wholesale Market, which introduced its first futures contract in October 1990. Between 1990 and 1993, there were about 50 futures exchanges in China, marked by a period of huge speculation and chaos. In 1994, the CSRC restructured the futures markets and reorganized all futures exchanges into three futures markets. They are Shanghai Futures Exchange (SHFE), Zhengzhou Commodity Exchange (ZCE) and Dalian Commodity Exchange (DCE). Apparently, the standardization and integration of the futures market create more uniform rules and healthy practices in the industry.

Transactions in overseas futures contracts by Chinese firms are possible, but they have to be first approved by both State Council and CSRC. The regulation stipulates that this overseas trading must be used for hedging purposes only. The goal is to preempt the speculation motive. However, some Chinese firms have violated the rule and thus created news in the financial markets.

During the development of the Chinese futures markets in the early 1990s, Chinese officials solicited advice from the Chicago Board of Trade (CBOT) executives to help set up its first futures exchange (Williams et al. 1998). Instead of the open outcry system in CBOT, China adopted an electronic trading system, which appeared to be more transparent and appropriate for China. 
In the literature, several studies have examined the behavior of futures markets in China (see Chan et al. 2004). Two aspects regarding the development of China's futures markets should be noted. First, it seems that government plays a critical role in developing the futures market by Chinese government, such as information disclosure. Second, the Chinese futures markets will emulate the developed financial markets over time. For example, Fung et al. (2003) investigate the pricing patterns of information flows for three commodity futures: copper, soybeans, and wheat traded in US and Chinese markets. The US futures market seems to play a dominant role in transmitting information to the Chinese market for two commodities (copper and soybeans) that are subject to less government regulation and fewer import restrictions in China. The heavily regulated and subsidized wheat commodity futures contracts are highly segmented in pricing, although there is some information transmission via volatility spillover across markets.

In Chan et al. (2004), they examine the intraday volatility of four futures contracts (copper, mungbeans, soybeans, and wheat) in China. They find that negative returns have more of an effect on volatility than positive returns do, while volume is positively related to volatility; open interest is negatively related to volatility. The large volume traders' participation is also positively related to volatility. The strong relationship of volatility to open interest, volume, and returns is more pronounced in recent periods than earlier periods. The volatility behavior of the Chinese futures market is quite similar to the developed financial market in the more recent period, a result indicating maturity of the market. The reason is likely due to the government policies that make the futures market more transparent through more information disclosure to the market.

The future development of China's futures may need to launch more commodity oriented futures contracts as China still has a large agricultural sector, where hedging against price fluctuations is important. In addition, China has become a key importer of metals such as copper and iron, as well as petroleum. Development of these futures markets would help prepare China for large price shocks. Historically, China once had the T-bond futures market, which was stopped in the late 1990s. Given the development of the T-bond market in recent years, it is important to reopen the T-bond futures market to benefit the growth of the T-bond market.

\section{RISK MANAGEMENT}

As China evolves from a central-planning economy to a market economy, we find that many concepts related to market risks are new to the institutions 
and practitioners. Without proper measures to avoid market price volatility resulting from speculation and noise, various market participants, including investors, firms and the government, may incur substantial losses. Therefore, it is important for the Chinese government to implement policies to help develop sound risk management practices among Chinese companies and financial intermediaries.

Various events illuminate the problems China has been facing in its financial reforms. For example, the Treasury bond futures market began trading on the Shanghai Stock Exchange in 1993. On 23 February 1995, the trading volume of the T-bond futures surged ten times to 100 billion yuan with the falling spot prices because short positions piled up. After a series of scandals and speculative trading, the CSRC closed down the T-bond futures market (Poon et al. 1998).

In December 2004, five executives of China Aviation Oil, a state-owned company, were arrested after its Singapore branch recorded losses of $\$ 554$ million in speculative oil derivatives trading. Although the Chinese government has rules on derivatives trading, these rules were obviously not properly enforced and implemented.

In November 2005, Liu Qibing, a trader for China's State Reserve Bureau (SRB) had accumulated massive short positions in copper on the London Metal Exchange (LME). The short-selling (sales of copper, he did not own, in hopes of buying it back later at a lower price) has left China short of copper by some 100000-200000 tonnes (The Economist, 18 November 2005).

Problems at China's securities brokerages have been a major obstacle to the development of the capital markets. About 90 percent of the securities firms are believed to be losing money and many have inadequate equity capital. In addition, the industry uses a mixture of reckless proprietary trading and poor risk management practices, which inevitably led to heavy losses. Securities firms lost about \$1.8 billion in 2004 (Financial Times, 18 November 2005).

In light of the ever-increasing market volatility, the Chinese government needs to implement policies to encourage Chinese firms to adopt good risk management practices. As a first step, CSRC, China's capital markets regulator, has allowed 31 companies to trade foreign financial derivatives to hedge their exposure in commodity prices.

Another important aspect of risk management in the financial sector, to a large extent, depends on rules and laws governing the operations of financial firms and how these rules and laws are implemented. A sound regulatory framework of the capital market is critical in the future development of China's capital market. At the same time, China will have to balance and safeguard the national interests of the financial services sectors 
in light of external shocks and its WTO commitments to removing restrictive barriers to help the economy.

\section{CONCLUDING REMARKS}

This chapter introduces and examines the development and challenges in China's capital markets. It serves as a building block for the following chapters on various aspects of China's capital markets such as stock market, bond market, financial intermediations, foreign exchange market and futures markets. As China's capital market emerges, it shares many characteristics with other emerging financial markets. Our analysis echoes the review study of Chan et al. (2006), which discusses various underlying factors in the development and growth of China's capital market.

In this chapter, we present a broad perspective on the overall development of China's capital market and compare it with some other emerging markets. China's capital market faces tremendous challenges during the development stage and it will continue to evolve over time. It serves as an interesting experiment for other emerging markets to evaluate. The limited growth in China's bond market and its future development also present us with interesting lessons to be learned. Certain issues deserve further review, such as how to balance the T-bond market with the corporate bond markets, and what types of futures markets should be developed.

Determining the proper roles financial intermediaries should play in an emerging market requires a deeper understanding of finance theories. China's reforms of its capital market and financial industries through a trial-and-error approach provide a unique learning opportunity for finance researchers. It is an important experiment that financial economists cannot ignore.

\section{ACKNOWLEDGMENT}

We thank Jennifer Dennis for editorial assistance.

\section{REFERENCES}

Chan, Kam, C., H. G. Fung and W. K. Leung (2004), 'Intraday volatility behavior in Chinese futures markets', Journal of International Financial Markets, Institutions, and Money, 14, 491-505.

Chan, Kam, C., H. G. Fung and Samanta Thapa (forthcoming), 'China financial research: a review and synthesis', International Review of Economics and Finance. 
China Securities Regulatory Commission (2004), 'China's securities and futures markets', working paper, April.

Fung, H. G., W. K. Leung and X. E. Xu (2003), 'Information flows between the US and China commodity futures trading', Review of Quantitative Finance and Accounting, 21, 267-85.

Fung, H. G., W. K. Leung and J. Zhu (2004), 'Non-deliverable forward market for Chinese RMB: a first look', China Economic Review, 15(3), 348-52.

Fung, Hung-Gay and Qingfeng Liu (2006), 'China's financial reform in banking and securities markets', in H. G. Fung, C. H. Pei and Kevin Zhang (eds), China and the Challenge of Economic Globalization: The Impact of WTO Membership, New York: M. E. Sharpe, pp. 145-63.

Fung, Hung-Gay, Wai Lee and W. K. Leung (2000), 'Segmentation of the A- and B-share Chinese equity markets', Journal of Financial Research, 23, 178-95.

Huang, A. G. and H. G. Fung (2004), 'Stock ownership segmentation, floatability and constraints on investment banking in China', China and World Economy, 12(2), 66-78.

Ling, Teresa and Jot Yau (2005), 'China' state share reform and exchange traded funds', China and World Economy, 13(16), 52-65.

Poon, Winnie, Michael Firth and Hung-Gay Fung (1998), 'The spillover effects of the trading suspension of the treasury bond futures markets in China', Journal of International Financial Markets, Institutions, and Money, 8, 205-18.

Wang, Li (2005), A Guide to Listing on and Investment in the Small- and MediumEnterprise Board, Beijing: The China Machine Press.

Williams, Jeffrey, Anne Peck, Albert Park and Scott Rozelle (1998), 'The emergence of a futures market: mungbeans on the China Zhengzhou Commodity Exchange', Journal of Futures Markets, 18(4), 427-48.

$\mathrm{Xu}$, Xiaoqing (2005), 'Performance of securities investment funds in China', Emerging Markets Finance and Trade, 41(5), 27-42.

Zhang, Mingli and Hui Liu (2001), 'People's Republic of China', in Yun-Hwan Kim (ed.), Government Bond Market Development in Asia, Manila: Asian Development Bank, Chapter 5. 
Kam C. Chan, Hung-gay Fung, and Qingfeng 'Wilson' Liu - 9781847205315 Downloaded from PubFactory at 04/26/2023 03:18:10PM 